\title{
Somatic embryogenesis and plant regeneration in oil palm using the thin cell layer technique
}

\author{
Jonny E. Scherwinski-Pereira • Rodrigo S. da Guedes • \\ Paulo César P. Fermino Jr • Tatiane L. Silva • \\ Frederico Henrique S. Costa
}

Received: 2 September 2008 / Accepted: 10 February 2010/Published online: 26 March 2010 / Editor: D. T. Tomes

(C) The Society for In Vitro Biology 2010

\begin{abstract}
An efficient procedure has been developed for inducing somatic embryogenesis and regeneration of plants from tissue cultures of oil palm (Elaeis guineensis Jacq.). Thin transverse sections (thin cell layer explants) of different position in the shoot apex and leaf sheath of oil palm were cultivated in Murashige and Skoog (MS) (Physiol Plant 15:473-497, 1962) medium supplemented with $0-450 \mu \mathrm{M}$ picloram and 2,4-D with $3.0 \%$ sucrose, $500 \mathrm{mg} \mathrm{L}^{-1}$ glutamine, and $0.3 \mathrm{gL}^{-1}$ activated charcoal and gelled with $2.5 \mathrm{gL}^{-1}$ Phytagel. Embryogenic calluses were evaluated $12 \mathrm{wk}$ after inoculation. Picloram $(450 \mu \mathrm{M})$ was effective in inducing embryogenic calluses in $41.5 \%$ of the basal explants. Embryogenic calluses were maintained on a maturation medium composed of basal media, plus $0.6 \mu \mathrm{M}$ $\mathrm{NAA}$ and $12.30 \mu \mathrm{M} 2 \mathrm{iP}, 0.3 \mathrm{gL}^{-1}$ activated charcoal, and $500 \mathrm{mg} \mathrm{L}^{-1}$ glutamine, with subcultures at 4-wk intervals. Somatic embryos were converted to plants on MS medium with macro- and micronutrients at half-strength, $2 \%$ sucrose, and $1.0 \mathrm{gL}^{-1}$ activated charcoal and gelled with $2.5 \mathrm{gL}^{-1}$ Phytagel.
\end{abstract}

J. E. Scherwinski-Pereira $(\bowtie)$

Embrapa Genetic Resources and Biotechnology,

Laboratory of Tissue Culture and Plant Conservation,

P. O. Box 02372, Brasília, DF, Brazil

e-mail: jonny@cenargen.embrapa.br

R. S. da Guedes • P. C. P. Fermino Jr

Department of Plant Science, Federal University of Acre,

P. O. Box 500, Rio Branco, AC, Brazil

T. L. Silva

Department of Biotechnology, Federal University of Amazonas, 69077-000 Manaus, AM, Brazil

F. H. S. Costa

Department of Plant Science, Federal University of Lavras,

P. O. Box 3037, Lavras, MG, Brazil
Keywords Elaeis guineensis · Oil palm · Somatic embryogenesis $\cdot$ Morphogenesis $\cdot$ Micropropagation

\section{Introduction}

Oil palm is a perennial oleaginous monocotyledonous plant predominantly cultivated in humid tropical regions of Africa, Latin America, and Southeast Asia. It produces two different oils, which can be obtained from the fruit mesocarp (palm oil) and the kernel from the seed endosperm (palm kernel oil) (Konan et al. 2006). With more than 8 million ha under cultivation worldwide and yields of up to 5-7 $\mathrm{t}$ oil ha $\mathrm{hr}^{-1} \mathrm{ynder}^{-1}$ optimum agroecological conditions, oil palm is currently the second major source of vegetable oil in the world after soybean (Maizura et al. 2006). Also, the production costs for palm oil in its ecosystem are the lowest among all the crops (Graille and Pina 1999).

Oil palm cultivation exploits almost exclusively the Elaeis guineensis species, whose origin is on the African Continent (Zeven 1964). There is, however, another species in the genus, Elaeis oleifera, found in the Amazon forest and known in Brazil as 'Caiuaé'. This species has been incorporated into oil palm breeding programs (Barcelos 1986; Santos 1991). The interest in the 'Caiuaé' germoplasm is that some traits of the species could be valuable to oil palm breeding. These traits are slow growth, oil quality (mostly unsaturated oil), and disease resistance, including resistance to lethal yellowing, the major problem of oil palm cultivation in America (Bergamin Filho et al. 1998), as well as Fusarium wilt, the major oil palm disease of Africa (Renard et al. 1980; Hardon et al. 1985). In the Amazon forest, 'Caiuaé' population is usually found near rivers on fertile and well-drained lands known locally as 
"Indian black lands" (Barcelos 1986). Extensive collections of 'Caiuaé' germoplasm were done in the Amazon river basin by EMBRAPA (Empresa Brasileira de Pesquisa Agropecuária, Brazil) and IRHO (Institut de Recherches pour les Huiles et Oleagineux, France) in the early 1980s, constituting a valuable source of genetic material.

The cultivation of 'Caiuaé' is still not viable economically because of smaller yields compared to the African oil palm. However, since the two species hybridize easily, interespecific hybrids can be obtained with yields around $90 \%$ of the commercial oil palm yields (Moretzsohn et al. 2002). Nevertheless, oil palm breeding is still in its infancy in terms of numbers of generations of improved plant material made available to planters. All commercial oil palm is F1 hybrid with either a selection of small kernels (dura) or large kernels (pisifera). The hybrids (tenera) show very high variation in oil yields with the best plants yielding $40 \%$ more than average. Advances in selection for agronomically important traits, such as fruit quality or disease resistance, have been slow because of the long generation time of this tree crop (Saaidi 1992). Natural reproduction of oil palm occurs exclusively by seeds and as a monocotyledonous species with a single growing apex; the plant does not produce axillary or basal shoots and cannot be multiplied vegetatively (Rajesh et al. 2003).

In this context, the in vitro cloning of elite palms through somatic embryogenesis has been proposed to take advantage of the high degree of variability, which still resides among improved progenies. By using this technology, the increase in oil production has been estimated to reach up to $30 \%$ (Soh 1986). Clonal propagation also has the advantage that secondary characters such as reduced palm height and superior oil quality found in selected individual palms could be uniformity expressed in all of the respective clones (Parajothy et al. 1989). Extensive research from the 1970s through the 1980s has been successful in regenerating oil palm plants from tissue culture (Rabechault et al. 1976; Pannetier et al. 1981; Paranjothy and Othman 1982; Nwankwo and Krikorian 1983; Duval et al. 1988; Teixeira et al. 1993; Rival et al. 1998; Tarmizi et al. 2004), all using somatic embryogenesis. Unfortunately, many details regarding tissue culture on oil palm are not available, because the research was generally carried out by commercial firms.

Somatic embryogenesis is the preferred in vitro regenerative route for palms (Steinmacher et al. 2007) and can be described as the process by which haploid or diploid somatic cells develop into structures that resemble zygotic embryos (i.e., bipolar structures without any vascular connection with the parental tissue) through an orderly series of characteristic embryological stages without fusion of gametes (Williams and Maheswaran 1986; Raemakers et al. 1995). This morphogenetic route is influenced by several factors imposed by in vitro conditions (Fehér et al. 2003). Among these, the explant source and the developmental stage are considered key elements that alter cellular competence (Merkle et al. 1995; Steinmacher et al. 2007).

The thin cell layer (TCL) technique consists of explants of small size excised from different plant organs either longitudinally (iTCL) or transversally (tTCL) (Silva 2003) and was first described in Nicotiana tabacum (Van Tran Thanh 1974). Although the TCL technique has been effectively used in the micropropagation of other species (Nhut et al. 2003; Steinmacher et al. 2007), to date, no reference is available regarding the use of this source of material for oil palm tissue culture studies.

In this paper, we report the transverse thin cell layer associated with different Picloran and 2,4-D concentrations on oil palm to establish an efficient system for somatic embryogenesis and plant regeneration.

\section{Materials and Methods}

Plant material and preparation of TCL explants. The study was carried out using explants obtained from young plants of Elaeis guineensis (Jacq.) Dura type, 8 to $10 \mathrm{~cm}$ in height, collected at the experimental area of Embrapa Acre, Acre State, Brazil. For obtaining the TCL explants, plants were initially rinsed in tap water for $5 \mathrm{~min}$, followed by surface sterilization through immersion during $15 \mathrm{~s}$ in $70 \%$ ethanol, and then in sodium hypochlorite solution, provided by a solution of $50 \%$ commercial bleach (2.0-2.5\% active chlorine), plus one drop of tween- $20^{\circledR}$ in each $100 \mathrm{~mL}$. Thereafter, under aseptic conditions, the material was rinsed three times in sterile distilled water. Afterward, the leaves, roots, and most external green leaves were removed, and the remaining tissue was transversely sectioned in $0.8-1.0-\mathrm{mm}$ slices, resulting in thin cell layer tissues at different histogenic layers. Some of these explants were composed only of subapical tissue or of leaf sheath and apical meristem, as well as different developmental stages. A similar procedure was described for Bactris gasipaes (Steinmacher et al. 2007), although in the present study the explants were evaluated as basal, middle, and apex segments. Of each one position, six transverse slices were obtained (Fig. 2A). Thus, 18 transverse sections were obtained from one plant. The original orientation of the explant was maintained during the inoculation.

Media and culture conditions. TCL explants were inoculated on Murashige and Skoog (MS) (1962) with 3.0\% sucrose, $500 \mathrm{mg} \mathrm{L}^{-1}$ glutamine, and $0.3 \mathrm{gL}^{-1}$ activated charcoal and gelled with $2.5 \mathrm{gL}^{-1}$ Phytagel $^{\circledR}$ (Sigma, St. Louis, MO). Picloran and 2,4-D were added at different concentrations $(0,225$, or $450 \mu \mathrm{M})$ to evaluate its effect on 
the production of embryogenic calluses. Embryogenic calluses were evaluated $12 \mathrm{wk}$ after inoculation. No subculture was applied until embryogenic calluses were obtained.

The embryogenic calluses were maintained in a maturation medium composed of basal media, plus $0.6 \mu \mathrm{M}$ NAA and $12.30 \mu \mathrm{M} 2 \mathrm{iP}, 0.3 \mathrm{gL}^{-1}$ activated charcoal, and $500 \mathrm{mg} \mathrm{L}^{-1}$ glutamine, with subcultures at 4 -wk intervals. To convert somatic embryos into plants, they were transferred to modified medium with the macro- and micronutrients at half-strength of $2 \%$ sucrose and $1.0 \mathrm{gL}^{-1}$ activated charcoal and gelled with $2.5 \mathrm{gL}^{-1}$ Phytagel $^{\circledR}$.

All culture medium had adjusted to $\mathrm{pH} 5.8$ prior to adding the gelling agent and were autoclaved for $15 \mathrm{~min}$ at $1.3 \mathrm{kgf} \mathrm{cm}^{-2}$. During the induction and maturation of somatic embryos, the cultures were kept in the dark at $25 \pm$ $2^{\circ} \mathrm{C}$. For somatic conversion and plant growth, the cultures were kept in a growth chamber at $25 \pm 2^{\circ} \mathrm{C}$ under a 16-h light photoperiod with $35 \mu \mathrm{mol} \mathrm{m} \mathrm{m}^{-2} \mathrm{~s}^{-1}$ intensity provided by cool-white fluorescent lamps until they were $6-8 \mathrm{~cm}$ tall; then, they were acclimatized.

Histological analyses. To evaluate the histological alterations associated with somatic embryogenesis, somatic embryos at the last developmental stage and zygotic embryos obtained from mature seeds of oil palm were fixed for $48 \mathrm{~h}$ at $4^{\circ} \mathrm{C}$ in phosphate buffer $(0.1 \mathrm{M}, \mathrm{pH} 7.3)$ containing $2.5 \%$ glutaraldehyde solution (Sigma). Thereafter, the samples were washed with the same buffer without fixative and dehydrated in a graded alcohol series (30-100\%), twice for $15 \mathrm{~min}$ each in each solution, before being embedded in paraffin. Serial sections of $8 \mu \mathrm{m}$ were taken using a manual microtome, placed on a slide with a drop of water, and stained with safranin/fast green.
Statistical procedure. Three Picloran and 2,4-D concentrations were evaluated $(0,225$, or $450 \mu \mathrm{M})$, as was the effect of initial explant position (basal, middle, and apex), on embryogenic callus production. The experiment was a factor in a completely randomized design with six replicates and six explants per replicate. Effects of treatment were tested by analyses of variance (one-way ANOVA) at the 5\% level of significance (Zonta and Machado 1984); means were compared with Tukey's multiple range test at $95 \%$ significance. Prior to analysis, percentage data were arcsinsquare root-transformed.

\section{Results and Discussion}

Callus and somatic embryo induction. The first evaluation for embryogenic callus (EC) formation was performed only $90 \mathrm{~d}$ after the starting of the establishment of the explants in vitro (Fig. 1). However, after $7 \mathrm{~d}$ of cultivation, the formation of primary calluses (PC) started to be perceived around the TCL explants. Those calluses were yellowish and translucent, and after staying $65 \mathrm{~d}$ in that medium, the PC progressed from friable stage to embryogenic stage (Fig. 2B-D).

During that period, it was evident that the EC forming was significantly influenced by the interaction between the auxin treatment and explant positioning. In a general way, the TCL explants originating from the plant's basal region presented a greater EC formation when compared to the remaining tested positions. Those results are possibly due to the larger tissue quantity still slightly different or not differentiated (meristematic) present in this type of explant. So, a greater occurrence of ECs was observed when basal
Figure 1. Influence of explant position and treatment with auxins on embryogenic callus production of oil palm. Uppercase letters represent significant differences among the explant positions (at each explant treatment), and lowercase letters represent differences among the treatment (at each explant position) according to Tukey's test. T1 $0 \mu \mathrm{M}, T 2225 \mu \mathrm{M}$ 2,4-D, T3 $450 \mu \mathrm{M} 2,4-\mathrm{D}$, T4 $225 \mu \mathrm{M}$ picloram, T5 $450 \mu \mathrm{M}$ picloram.

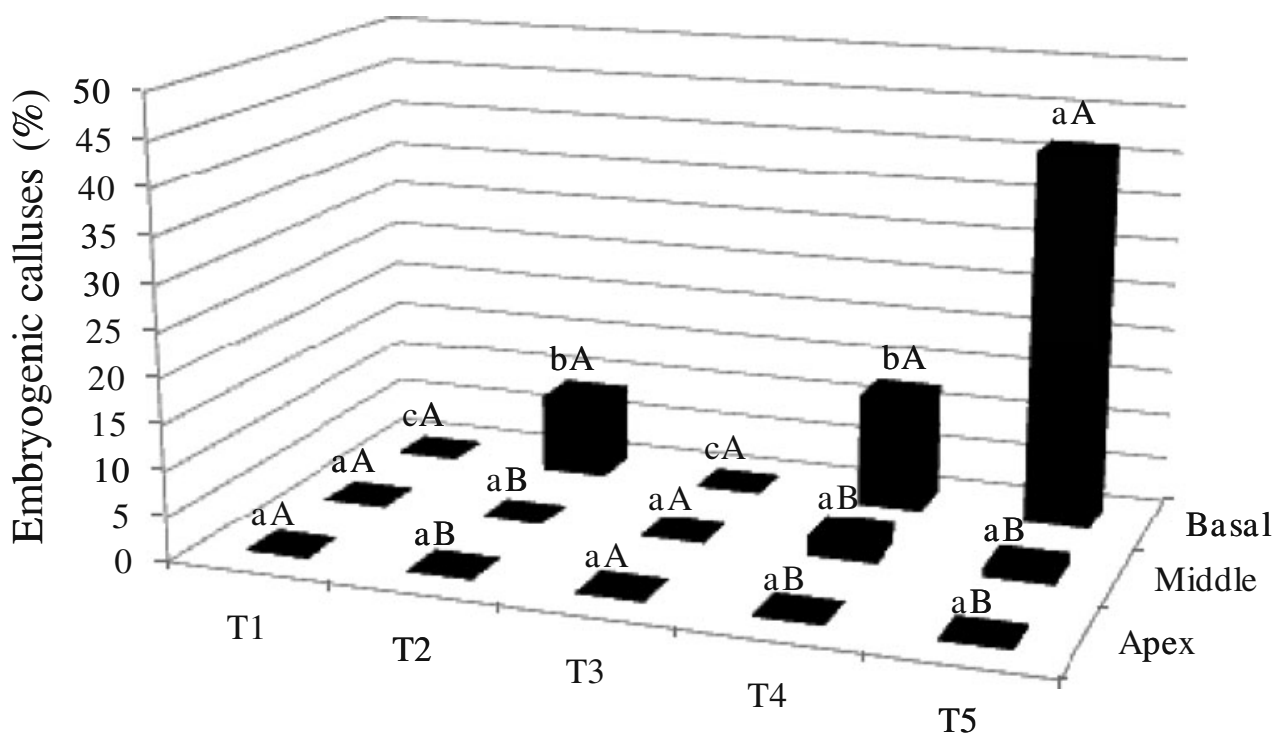

Springer 
Figure 2. Somatic embryogenesis from TCL explants of oil palm [Elaeis guineensis (Jacq.), Dura type]. A, Schematic diagram of young plants after removal of external leaves, showing at different histogenic layers (apex, middle, and basal) utilized as TCL explants; $B$, primary callus formation from basal TCLs $7 \mathrm{~d}$ in culture medium with picloram; $C, D$, Progression of embryogenic callus from primary callus; $E$, formation of somatic embryos from embryogenic callus; $F, G$, clusters of somatic embryos from embryogenic callus on maturation culture medium; $H$, morphological aspect between a somatic and a zygotic embryo; $I$, oil palm plants regenerated from somatic embryogenesis. Scale bars: $A, C, D, I=1 \mathrm{~cm} ; B, E, F$, $G, H=2 \mathrm{~mm}$.
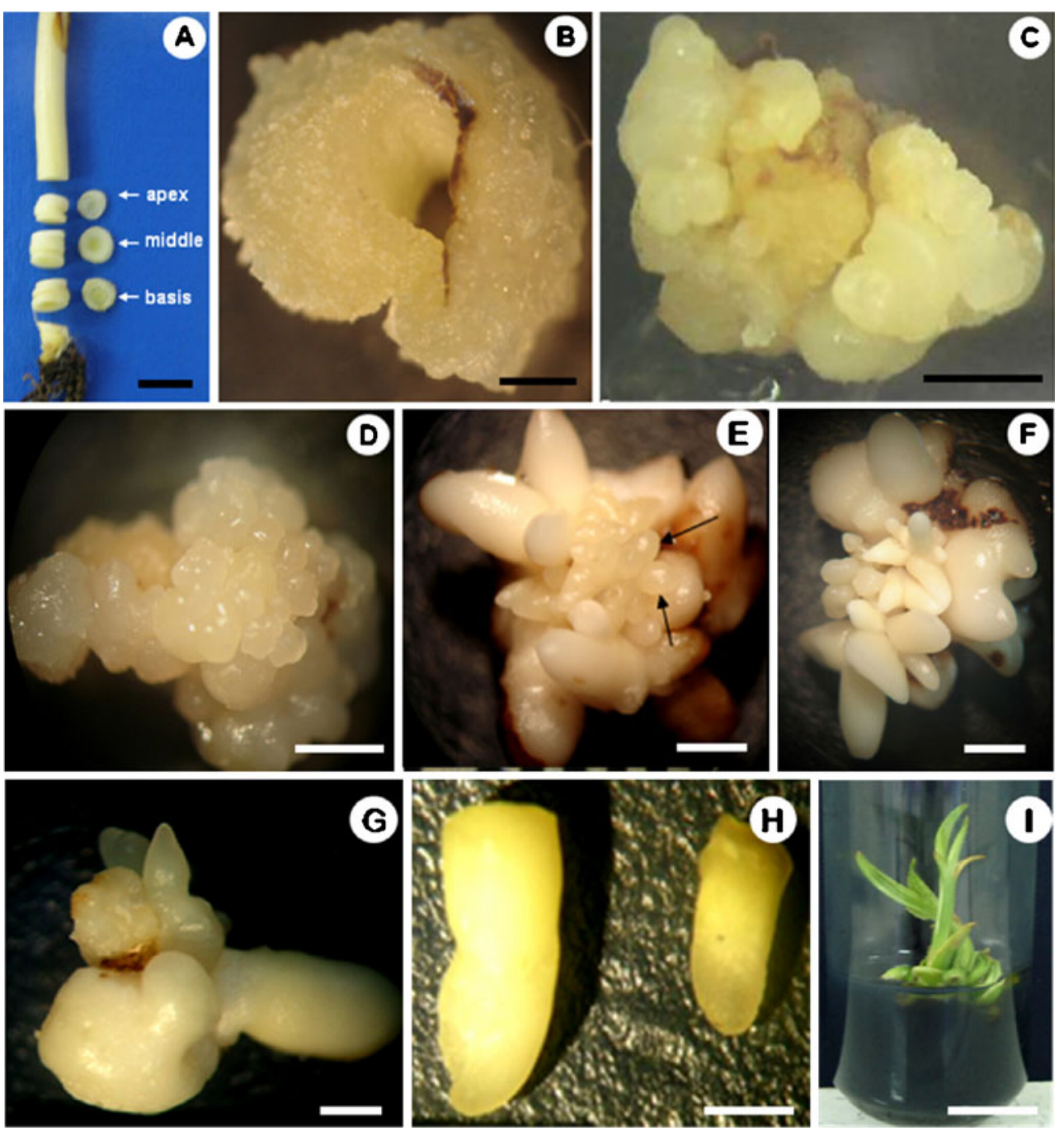

explants were used in a medium supplemented with $450 \mu \mathrm{M}$ Picloran (T5), with $41.5 \%$ of the explants responsive to that treatment, followed by the addition of $225 \mu \mathrm{M}$ picloram and 2.4-D (T4 and T2), with $12.8 \%$ and $8.8 \%$, respectively (Fig. 1). On the contrary, for the remaining TCL tested positions, no relevant difference was noticed in the auxin-based treatments. It must also be noted that no answer occurred in a medium without auxins or as a whole when using 2.4-D as auxin. Besides, when explants further from the plant's meristematic apex were used (apex and median), oxidizing was more intense.

The results were similar to those obtained in peach palm by Steinmacher et al. (2007), who noticed that the plant's explant position and the concentration of auxins were key factors for the cells to re-start their mitotic cycle and induce the somatic embryogenesis (SE) of that species. According to those authors, after a 5-mo cultivation, the EC formation (43\%) was significantly larger in TCL explants originating from the apex meristem region cultured in media containing $300 \mu \mathrm{M}$ picloram. On the other hand, concentrations superior to those $(600 \mu \mathrm{M})$ promoted reduction in the $\mathrm{EC}$ formation.

Since the first report of the TCL technique use, in 1974, by Tran Thanh Van et al., research has demonstrated its efficiency in regenerating plants of various species (Nhut et al. 2003), including palms (Samosir et al. 1998; Steinmacher et al. 2007). According to Silva (2003), the use of TCL explants may be a promising alternative to disrupt the predominance of intercellular symplasts and prevent interaction among organs usually found in more complex systems, such as in plants (Nhut et al. 2003). Furthermore, the TCL explants are a simplified system requiring just a small quantity of vegetable material and culture medium (15 $\mu \mathrm{L}$ per TCL), besides providing a good system for basic and applied studies, including those related to regeneration and transformation (Silva 2003). Additionally, Fehér et al. (2003) discuss that reduced-size explants have a specific, larger surface in contact with the culture medium, which might promote a better response of those with growth regulators. 
In the literature, there has been a consensus regarding the role of growth regulators added to the cultivation media in induction protocols of the embryogenic competence; auxins and cytokinins are the two most involved in the activation and regulation of the cellular division and differentiation (Geldner et al. 2000; Fehér et al. 2003). Considering those two categories of growth regulators, the exogenous application of the auxins considered strong, such as 2.4-D, have been well documented in showing how to induce the transition of somatic cells into embryogenic cells in many vegetal systems. One of the reasons for the wide use of 2.4-D is based on the fact that, above a certain concentration, that auxin creates a double effect, acting directly as an auxin or alternating the IAA endogenous metabolism, or even as a stressing factor (Fehér et al. 2003).

Specifically, in the case of the oil palm, most of the research conducted with some success to vegetatively multiply that species has used the SE process induced in a medium containing 2.4-D (Sogeke 1996). In that sense, Rival et al. (1997) report that the palm oil callogenesis is obtained in the dark and in a culture medium supplemented with 2.4-D, in a way that after $12-20$ wk, the EC are transferred to a secondary medium containing low 2.4-D concentrations for the formation of embryogenic structures. In a similar way, Teixeira et al. (1994) achieved the formation of calluses from young feminine inflorescences of palm oil only after 2 to 3 mo of cultivation in an MS medium modified and supplemented with 2.4-D $(475 \mu \mathrm{M})$. As an alternative, in addition to the 2.4-D, some works have evidenced the superiority of picloram in inducing the SE in several species of palms, including peach palms and arecanut palm (Valverde et al. 1987; Steinmacher et al. 2007).

The somatic embryos were developed in an unsynchronized way, in the same cluster, with a perceivable difference in the stages of development of the formed somatic embryos, with the presence of globular and mature somatic embryos with bipolar characteristics. Those characteristics were also noticed by Steinmacher et al. (2007), when embryogenic calluses were transferred to a regeneration medium. Likewise, Ledo et al. (2002) also observed an asynchrony in the development of somatic embryos in Euterpe edulis obtained from zygotic embryos cultured in the presence of 2.4-D.

Maturation and conversion of the somatic embryos. Aiming at the progression from early to late stages, mature somatic embryos from TCL explants in a medium containing picloram were transferred after a 90-d cultivation to an MS medium added by $0.6 \mu \mathrm{M}$ NAA and $12.30 \mu \mathrm{M} 2$-iP for maturation. Guerra et al. (1999) affirm that the maturation stage of embryogenic cultures consists in interrupting the repetitive cycles of the cell division and in providing physiologic, bio-chemical, and/or environment stimuli required for the cellular differentiation and the consequent maturation of the somatic embryos, which must present high quality and capability for conversion into plants.

Usually, the somatic embryo formation has been noticed when cultures originating from a medium rich in auxins are transferred to a secondary medium not provided with auxins or with a low auxin concentration (Rao and Ganapathi 1993). Fehér et al. (2003) affirm that the embryogenesis follows a double cycle. In the first cycle, when the induction and the development of the embryogenic cells take place, higher concentrations of auxins are required, while in the second, the reduction or absence of the auxin source is essential for promoting the development of pro-embryos and the subsequent formation of somatic embryos. Teixeira et al. (1994) succeeded in the development of globular structures that originated from high auxin concentrations (2.4-D) into somatic embryos, in a medium supplemented with NAA $(15 \mu \mathrm{M})$ and ABA $(2 \mu \mathrm{M})$ without activated charcoal. Those authors, however, noticed that 8 to $10 \mathrm{mo}$ was required from the callus formation stage duration and its differentiation in SE, called first stage of palm clone multiplication. After induction and maturation, another 2 mo was required for converting the SE in plants, performed in a culture medium formed by a half of the MS's mineral salts concentration, adding $1 \mathrm{gL}^{-1}$ of activated charcoal. Those culture conditions are noticed in a great number of the SE protocols, in which the germination stage of the somatic embryos usually occurs in a medium of culture in the absence of growth regulators (Namasivayam 2007), although some works reveal good effects through the use of growth regulators such as cytokinins (BA) in the SE germination in many species of plants (Anitha and Sajini 1996; Aberlenc-Bertossi et al. 1999).

Also, in the maturation stage, it was possible to notice that after $2 \mathrm{wk}$ in that medium, the SE showed characteristics of secondary somatic embryogenesis (SSE). The SSE, or adventitious embryogenesis, is a phenomenon in which new SE is initiated, originating from others that already existed. Their emergence may be a consequence of the predisposition of some groups of cells, in particular, that allow the expression of their totipotence (Williams and Maheswaran 1986). In experimental character, that type of embryogenesis has some advantage when compared to the primary SE of the high multiplication rate, regardless of an explant source, and a process of repetitiousness (Vasic et al. 2001). Additionally, the embryogenic potential can be held for long periods of time by repeated cycles of secondary embryogenesis (Raemakers et al. 1995).

Last, the mature-stage embryos obtained through this study were transferred to a medium without a growth regulator aiming at their regeneration in plants (Fig. 2I). The formation of normal plants from the palm oil SE was also noticed by 
Teixeira et al. (1994), when those embryos were transferred to a medium not provided with growth regulators.

Morpho-histological analyses. The histological observations obtained from a PC transversal section revealed proliferation of a meristematic zone, with prominent nucleus and dense cytoplasm, as well as parenchymal tissue, in addition to connecting vascular tissue with the explant and the callus's coating cells (Fig. 3). The results corroborated those obtained by Steinmacher et al. (2007). Raising TCL-type tissues in the presence of picloram in Bactris gasipae, obtained from internal foliage linings, Steinmacher noticed that the tissues developed a compact aspect, dark yellowish primary calluses with the formation of a meristematic zone.
At the SE length cut, the main characteristics observed were the presence of the apex meristem, procambial strand, and protoderm, in addition to cells with dense cytoplasm and prominent nucleus at the procambial strand tissue. According to Sané et al. (2006), histological analyses of Phoenix dactylifera (Arecaceae) compact primary calluses showed that they were formed by small meristematic cells with dense cytoplasm and rich in soluble proteins. Additionally, the small dividing cells had an embryogenic appearance, with a cytoplasm rich in protein, small vacuoles, and a large nucleus.

Regarding the zygotic embryo (ZE), morpho-histological analyses showed the presence of apex meristem and primordial leaves (Fig. $3 G$ ), thus characterizing the existence of similarities when compared to the SE's analyses.
Figure 3. Morpho-histological aspects of the oil palm somatic and zygotic embryos, Dura type. $A$, Traverse section of the primary callus evidencing proliferation of a meristematic zone $(z m)$ and parenchymatic tissue $(t p) ; B$, traverse section of the callus showing vascular tissue $(t v)$, meristematic zone $(\mathrm{zm})$, and coating cells of the callus $(\mathrm{cr})$; $C$, external morphology of the cluster obtained from TCL explants, showing somatic embryos; $D$, longitudinal section of the somatic embryo evidencing apex meristem ( $m a$ ), procambial strand $(c p c)$, and protodermis $(p d) ; E$, detail of the procambial strand $(p c)$ emphasizing cells with dense cytoplasm $(c d)$ and prominent nucleus $(n p)$; $F$, external morphology of the zygotic embryo; and $G$, longitudinal section of the zygotic embryo evidencing apex meristem $(m a)$ and leaf primordia ( $p f)$. Scale bars: $A=30 \mu \mathrm{m}, B=50 \mu \mathrm{m}, C=1 \mathrm{~cm}$, $D=100 \mu \mathrm{m}, E=10 \mu \mathrm{m}$, $F=2 \mathrm{~mm}, G=30 \mu \mathrm{m}$.
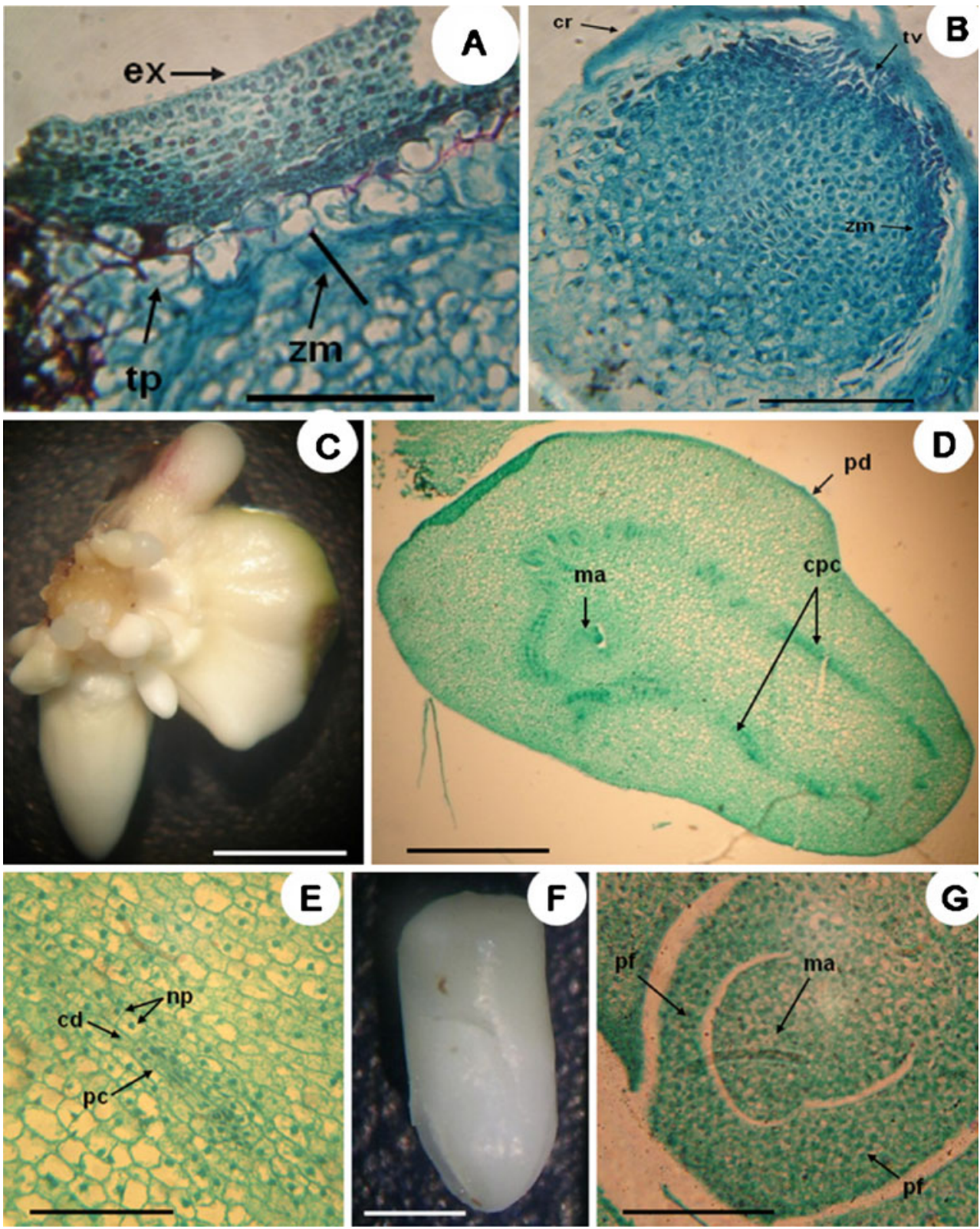
The findings are similar to those obtained by Kanchanapoom and Domyoas (1999), according to whom palm oil mature ZE shows a white color, oval shape, and the apex meristem surrounded by a simple cotyledon as characteristics and an internal cavity containing a characteristic zone of apex bud formed by an apex meristem and two to three primordial leaves. Besides, according to the authors, the cotyledon is formed by three types of cells called parenchyma, procambium, and protodermis. According to Sané et al. (2006), the key difference between the SE and ZE development is the low accumulation of reserves during the initial stage of the development. In that sense, Schwendiman et al. (1988) state that the early accumulation of lipid reserves in palm oil may be a good indicator of the acquisition of the embryogenic competence of the tissues.

Eucalyptus length-wise sections studied by Bandyopadhyay and Hamill (2000) have SE with a morphology and internal cell organization strictly similar to mature ZE. Both types of embryos presented cotyledon composed of tightly packed cells, and each consisted of a single outer layer of epidermal cells enclosing a palisade layer (one cell thick in the somatic embryo and one to two cells thick in the zygotic embryo) and several layers of parenchyma cells (three to four cells thick in the somatic embryo and four to five cells thick in the zygotic embryo). In addition, the shoot apex of the SE contained densely cytoplasmic cells with deeply stained nuclei, and cells in the meristematic zone were small, with prominent nuclei and nucleoli.

That study described the complete regeneration process of the palm oil plants through the SE associated with the TCL technique. In summary, the results achieved here suggest that the use of basal explants associated to high picloram concentrations $(450 \mu \mathrm{M})$ is a promising way for producing clonal palm oil, mostly for hybrids. Clonal propagation from hybrids also has the advantage of maintaining genetic characteristics such as reduced height and superior quality which, present in selected individual palms, could be uniformly expressed in all obtained clones.

Acknowledgment The authors thank the Conselho Nacional de Desenvolvimento Científico e Tecnológico-CNPq, Brasília, Brazil, for financial support and fellowships.

\section{References}

Aberlenc-Bertossi F.; Noirot M.; Duval Y. BA enhances the germination of oil palm somatic embryos derived from embryogenic suspension cultures. Plant Cell Tissue Organ Cult 56: 5357; 1999.

Anitha K.; Sajini K. K. Plantlet regeneration from leaf explants of oil palm. Curr Sci 71: 922-926; 1996.
Bandyopadhyay S.; Hamill J. D. Ultrastructural studies of somatic embryos of Eucalyptus nitens and comparisons with zygotic embryos found in mature seeds. Ann Bot 86: 237-244; 2000.

Barcelos E. Características genético-ecológicas de populações naturais de caiaué (Elaeis oleifera H.B.K.) na Amazônia brasileira. Thesis: Instituto Nacional de Pesquisas da Amazônia; 1986

Bergamin Filho A.; Amorin I.; Laranjeira F. F.; Berger R. D.; Hau B. Análise temporal do amarelecimento fatal do dendezeiro como ferramenta para elucidar sua etiologia. Fitopatologia Brasileira 23: 391-396; 1998.

Duval Y.; Durand-Gasselin T.; Konan K.; Pannetier C. In vitro vegetative propagation of oil palm (Elaeis guineensis Jacq.). Oléagineux 43: 45-47; 1988.

Fehér A.; Pasternak T. P.; Dudits D. Transition of somatic plant cells to an embryogenic state. Plant Cell Tissue Organ Cult 74: 201228; 2003.

Geldner N.; Hamann T.; Jurgens G. Is there a role for auxin in early embryogenesis? Plant Growth Regul. 32: 187-191; 2000.

Graille J.; Pina M. The role of palm oil in the human diet. Plant Recherché Dev 6: 91-93; 1999.

Guerra M. P.; Torres A. C.; Teixeira J. B. Embriogênese somática e semente sintética. In: Torres A. C.; Caldas L. S.; Buso J. A. (ed.) Cultura de Tecidos e Transformação Genética de Plantas. Embrapa-SPI/CNPH, Brasília, pp. 533-568; 1999.

Hardon J. J.; Rao V.; Rajanaidu N. A review of oil-palm breeding. In: Russell G. E. (ed) Progress in plant breeding. Butterworths, London, pp 139-163; 1985.

Kanchanapoom K.; Domyoas P. The origin and development of embryoids in oil palm (Elaeis guineensis Jacq.) embryo culture. Science Asia 25: 193-200; 1999.

Konan E. E.; Durand-Gasselin T.; Kouadio J. Y.; Flori A.; Rival A. A modeling approach of the in vitro conversion of oil palm (Elais guineensis) somatic embryos. Plant Cell Tissue Organ Cult 84: 99-112; 2006.

Ledo A. S.; Lameira A. O.; Benbadis A. K.; Menezes I. C.; Oliveira M.; Medeiros Filho S. Somatic embryogenesis from zygotic embryos of Euterpe edulis Mart. Rev Bras Frutic 24: 601-603; 2002.

Maizura I.; Rajanaidu N.; Zakri A. H.; Cheah S. C. Assessment of genetic diversity in oil palm (Elaeis guineensis Jacq.) using restriction fragment length polymorphism (RFLP). Genet Resour Crop Evol 53: 187-195; 2006.

Merkle A. S.; Parrott W. A.; Flinn B. S. Morphogenic aspects of somatic embryogenesis. In: Thorpe T. A. (ed) In vitro embryogenesis in plants. Kluwer, Dordrecht, pp 155-203; 1995.

Moretzsohn M. C.; Ferreira M. A.; Amaral Z. P. S.; Coelho P. J. A.; Grattapaglia D.; Ferreira M. E. Genetic diversity of Brazilian oil palm (Elaeis oleifera H.B.K.) germplasm collected in the Amazon Forest. Euphytica 124: 35-45; 2002.

Murashige T.; Skoog F. A revised medium for rapid growth and bioassays with tobacco tissue cultures. Physiol Plant 15: 473497; 1962.

Namasivayam P. Acquisition of embryogenic competence during somatic embryogenesis. Plant Cell Tissue Organ Cult 90: 1-8; 2007.

Nhut D. T.; Silva J. A. T.; Aswath C. R. The importance of the explants on regeneration in thin cell layer technology. In Vitro Cell Dev Biol Plant 39: 266-276; 2003.

Nwankwo B. A.; Krikorian A. D. Morphogenetic potential of embryo and seedling-derived callus of Elaeis guineensis Jacq. Var. psifera Becc. Ann Bot 51: 65-76; 1983.

Pannetier C.; Arthuis P.; Liévoux C. Néoformation de jeunes plants de Elaeis guineensis à partir de cals primaires obtenus sur fragments foliares cultivés in vitro. Oléaginoux 36: 119-122; 1981.

Paranjothy K.; Othman R. In vitro propagation of oil palm. In: Fugiwara A. (Ed) Plant Tissue Culture. Proceeding 5th International 
Congress of Plant Tissue and Cell Culture. Tokyo, pp. 747-748; 1982.

Parajothy K.; Rohani O.; Tarmizi A. H.; Tan C. C. Current status and strategies of oil palm tissue culture research. PORIM, Int. Palm Oil Development Conference, Malaysia, pp. 109-121; 1989

Rabechault H.; Ahee J.; Guenin G. Recherches sur la culture in vitro des embryos de palmier a huile (Elaeis guineensis Jacq.). XII. Effects de substances de croissance a des doses supraoptimales. Relation avec le brunissement des tissues. Oleagineux 31: 159$163 ; 1976$.

Raemakers C. J. J. M.; Jacobsen E.; Visser R. G. F. Secondary somatic embryogenesis and applications in plant breeding. Euphytica 81: 93-107; 1995.

Rajesh M. K.; Radha E.; Karun A.; Parthasarathy V. A. Plant regeneration from embryo-derived callus of oil palm - the effect of exogenous polyamines. Plant Cell Tissue Organ Cult 75: 4147; 2003 .

Rao P. S.; Ganapathi, T. R. Micropropagation of palms. In: Ahuja M. R. (ed) Micropropagation of woody plants. Springer, Berlin, pp 405-421; 1993.

Renard J. L.; Noiret J. M.; Meunier J. Sources and ranges of resistance to Fusarium wilt in the oil palm Elaeis guineesis and Elaeis melanococca. Oléagineux 35: 387-392; 1980.

Rival A.; Berlenc F. A.; Morcillo F.; Tregear J.; Verdeil J. L.; Duval Y. Scaling-up in vitro clonal propagation through somatic embryogenesis: the case of oil palm (Elaeis guineensis Jacq). Plant Cell Tissue Organ Cult 3: 74-83; 1997.

Rival A.; Bertrand L.; Beulé T.; Trouslot P.; Lashermes P. Suitability of RAPD analysis for the detection of somaclonal variants in oil palm (Elaeis guineensis Jacq.). Plant Breeding 117: 73-76; 1998

Saaidi M. Comportement au champ de 32 cultivars de palmier dattier vis-à-vis du bayoud: 25 années d'observations. Agronomie 12: 359-370; 1992.

Samosir Y. M. S.; Godwin I. D.; Adkins S. W. An improved protocol for somatic embryogenesis in coconut (Cocos nucifera L.). Acta Horticult. 461: 467-474; 1998.

Sané D.; Aberlenc-Bertossi F.; Gassama-Dia Y. K.; Sagna M.; Trouslot M. F.; Duval Y.; Borgel A. Histocylogical analysis of callogenesis and somatic embryogenesis from cell suspension of date palm (Phoenix dactylifera). Ann Bot 98: 301-308; 2006.

Santos M. M. Polimorfismo isoenzimático de população subspontânea de dendê (E. guineensis Jacq.) do estado da Bahia e sua relação genética com seis procedências africanas. PhD Thesis. Universidade de São Paulo; 1991.

Schwendiman J.; Pannetier C.; Michaux-Ferriere N. Histological of somatic embryogenesis from leaf explants of the oil palm Elaeis guineensis. Ann Bot 62: 43-52; 1988.

Silva J. A. T. Thin cell layer technology in ornamental plant micropropagation and biotechnology. Afr J Biotech 2: 683-691; 2003.

Sogeke A. K. Rapid callus proliferation, somatic embryogenesis and organogenesis of oil palm (Elaeis guineensis Jacq.). Elaeis 8: 92 $103 ; 1996$.

Soh A. C. Expected yield increase with selected oil palm clones from current seedling material. Oleagineux 41: 51-56; 1986.

Steinmacher D. A.; Krohn N. G.; Dantas A. C. M.; Stefenon V. M.; Clement C. R.; Guerra M. P. Somatic embryogenesis in peach palm using the thin cell layer technique: Induction, morphohistological aspects and AFLP analysis of somaclonal variation. Ann Bot 49: 1-11; 2007.

Tarmizi A. H.; Norjihan M. A.; Zaiton R. Multiplication of oil palm suspension cultures in a bench-top (2-litre) bioreactor. $J$ Oil Palm Res 16: 44-49; 2004.

Teixeira J. B.; Sondahl M. R.; Kirby E. G. Somatic embryogenesis from immature zygotic embryos of oil palm. Plant Cell Tissue Organ Cult 34: 227-233; 1993.

Teixeira J. B.; Sondahl M. R.; Kirby E. G. Somatic embryogenesis from immature inflorescences of oil palm. Plant Cell Rep 13: 247-250; 1994.

Van Tran Thanh K. Direct flower neoformation from superficial tissue of small explants of Nicotiana tabacum L. Planta 115: 87-90; 1974.

Valverde R.; Arias O.; Thorpe T. A. Picloran-induced somatic embryogenesis in pejibaye palm (Bactris gasipaes HBK). Plant Cell Tissue Organ Cult 10: 149-156; 1987.

Vasic D.; Alibert G.; Skoric D. Protocols for efficient repetitive and secondary somatic embryogenesis in Helianthus maximiliani (Schrader). Plant Cell Rep 20: 121-125; 2001.

Williams E. G.; Maheswaran G. Somatic embryogenesis: factors influencing coordinated behavior of cells as an embryogenic group. Ann Bot 57: 443-462; 1986.

Zeven A. C. On the origin of the oil palm. Grana palynologica 5: $121-123 ; 1964$.

Zonta E. P.; Machado A. A. SANEST-Sistema de Análise Estatística para Microcomputadores. Universidade Federal de Pelotas, Pelotas; 1984. 